\title{
Visual Aesthetics Understanding of Elementary Students in Creating the Artworks
}

\author{
Probosiwi, ${ }^{\text {a,1,*, }}$ Yuni Hastuti ${ }^{\text {b,2 }}$ \\ an Elementary Teacher Education Department of Universitas Ahmad Dahlan Yogyakarta, Indonesia \\ ${ }^{b}$ SD Negeri Bhayangkara Yogyakarta Indonesia \\ ${ }^{1}$ probosiwi@pgsd.uad.ac.id*; ${ }^{2}$ yunihastuti037@gmail.com \\ * corresponding author
}

ARTICLE INFO

Article history

Received 2019-11-01

Revised 2019-11-15

Accepted 2019-11-30

Keywords

Visual Aesthetics

Creativity

Visual Art Education

\section{ABSTRACT}

This research has motivated by the author's desire to know deeply about elementary students' understanding of visual aesthetics through the objectification process. The purpose of this research is to explore the ability of elementary school students to interpret the beauty and visual arts through practical activities in making three-dimensional artworks. The author using qualitative research methods with data collection techniques are observation, interviews, and document reviews. The subjects are students in Grade 6 at SD Negeri Bhayangkara Yogyakarta. The data analysis technique used is narration. The results are obtaining students taking the stages in making artworks with a visual aesthetic approach and the objectification process towards natural objects. Visual aesthetic understanding for elementary students comes from how we can invite them doing practicing at outclass and let them look for reference from many sources. Creativity reveals from combining person, product, process, and environment. The involvement of the lecturer and tutor teacher in the learning process is beneficial for students in representing ideas and ideas. Besides, the process of mentoring during practice can control the attitudes of those who tend to play around still.

This is an open-access article under the CC-BY-SA license.

\section{Introduction}

Based on "Badan Pengembangan dan Pemberdayaan Sumber Daya Manusia Kesehatan" uploading on page bppsdmk.kemkes.go.id, "Kata Kerja Operasional (KKO)" for elementary school students in the realm of understanding is in point $\mathrm{C} 2$, namely interpreting the concepts or rules of a material object that is discussed at a meeting in the class [1]. At this stage, students in Grade 6 have directed to be able to interpret three-dimensional (3D) by definition, type of media, materials, tools, and the steps of making the artworks. "Seni Budaya dan Prakarya (SBdP)" course in Grade 6 must accord to Core Competencies (KI) and Basic Competencies (KD). The author put Core Competencies 3 (Cognitive), which discuss competencies achievement to understand factual and conceptual knowledge by observing, asking, and trying based on curiosity about themselves, God's creatures, and their activities, and objects encounter at their home, at school, and playgrounds. Then, Basic Competencies 4 (Psychomotor) have competence consists of presenting factual and conceptual knowledge in explicit, systematic, logical, and critical language, in artistic works, in movements that reflect healthy children, and in actions that reflect the behavior of children of faith and noble character. The Basic Competencies will be achieved are 3.1. To understand billboards; 3.2. To follow tone intervals; 3.3. To understand dance performances of regional creations; 3.4 to understand sculpture; 4.1 making the billboards; 4.2 playing tone intervals with songs and instruments; 4.3 performing the local dance creations; 4.4 making the sculpture, seen in Table 1. 
Table 1. "Seni, Budaya, dan Prakarya" Lesson for $6^{\text {th }}$ Grade Elementary Students on Sculpture and Advertising

\begin{tabular}{|c|c|c|}
\hline Week & Lesson & Lesson Description \\
\hline 1 & Learning Contract & $\begin{array}{l}\text { Lecturer and Tutor Teacher are getting acquainted with the students. } \\
\text { Lecturer describing the lesson that will be discussed for eight times a meeting } \\
\text { every week. }\end{array}$ \\
\hline 2 & Art Insight & $\begin{array}{l}\text { Lecturer, Tutor Teacher, and students are making studying agreement. } \\
\text { Art definition. } \\
\text { Classification of Art. } \\
\text { Techniques for making arts. } \\
\text { Examples of Arts. }\end{array}$ \\
\hline 3 & $\begin{array}{l}3 \text { Dimensional Visual } \\
\text { Arts Insight }\end{array}$ & $\begin{array}{c}\text { Sculpture Definition. } \\
\text { Classification of Sculpture. } \\
\text { Techniques on Making Sculpture. } \\
\text { Video Sculpture Making. } \\
\text { Assignment: division of materials classification groups and preparation of } \\
\text { tools. Tools: cutters, knives, toothbrushes. Material: bath soap. }\end{array}$ \\
\hline 4 & $\begin{array}{l}\text { The Practice of Making } \\
\text { Sculpture }\end{array}$ & $\begin{array}{l}\text { Steps of Making Sculpture. } \\
\text { Practical assistance. }\end{array}$ \\
\hline 5 & $\begin{array}{l}2 \text { Dimensional Visual } \\
\text { Arts Insight }\end{array}$ & $\begin{array}{l}\text { Practice making a sculpture from bath soap with an outing class. } \\
\text { Definition of Advertising. } \\
\text { Techniques for Making Advertising. } \\
\text { Photos of Advertising Artworks. } \\
\text { Assignment: preparing tool and material. Tools: pencil 2B, eraser, brush, } \\
\text { palette. Material: Poster color, art paper A3, wiping cloth. }\end{array}$ \\
\hline 6 & $\begin{array}{l}\text { The practice of Making } \\
\text { Advertising }\end{array}$ & $\begin{array}{c}\text { Steps of making advertising on the two-dimensional field using wet media } \\
\text { (poster color). } \\
\text { The practice of making advertising with the lecturer and tutor teacher } \\
\text { assistance. } \\
\text { Artworks are finishing. }\end{array}$ \\
\hline 7 & $\begin{array}{c}\text { Exhibition } \\
\text { Management }\end{array}$ & $\begin{array}{l}\text { Visual Arts Exhibition Insight. } \\
\text { Exhibition planning. }\end{array}$ \\
\hline 8 & Artworks Exhibition & Class exhibition. \\
\hline
\end{tabular}

The author is doing the study about primary students toward visual aesthetic for creating the artworks. The author is taking the two core competencies for learning them in point 3.1 to understanding advertising; 3.4 to understand sculpture, while for based skills, the author has chosen location 4.1 making advertising and 4.4 making sculpture. Students have given sculpture topics consisting of the definition, type, classification, and steps for making the sculpture. Students have given visual references about sculpture and media, which they can prepare the practice. According to Sparks, theorists support the development of these competencies but recommend that visual arts education should be framed around critical thinking, and not focus predominantly on formal artmaking skills. The inclusion of visual literacy and an analytical inquiry framework around images that expose diverse issues is essential for meaningful art-making by students [2]. So, every student must have a visual reference and representing they're observed into their idea for the artworks.

Arts-Based Research (ABR) has been expanding in its use to understand and explore topics important for issues of equity and social justice, allowing researchers to reach a wider audience. Researchers have found incorporating arts-based research (ABR) a useful tool to address sensitive topics. Within educational research, ABR supports new perspectives Arts-based educational research is founded on the belief that the arts can contribute particular insights into, and enhance understandings of phenomena that are of interest to educational researchers. Visual arts as a tool for phenomenology founded on the belief that the skills can contribute particular insights into, and enhance understandings of phenomena that are of interest [3]. Art is an explicitly creative area, and art may meet with creativity in a shared vision. In this approach, it can be said that the link (between technique and creativity) is based on novelty because both art and creativity phenomena require innovation indefinitely. As a result, the connection between art and creativity has been established again and again as inevitable [4]. The interpretation of creativity and its processes is diverse; however, creativity can also refer to a person, process, and product which deemed to be original and useful or adaptive. The creativity process involves exploring and gathering different inspirations, ideas, experimentation, and creation. As students in the Elementary Teacher Education Department, they must be collaborating with such ideas, techniques, art insight, and knowing the character of 
objects [5]. A large number of overlapping abilities that must be utilized in visual art-making, perception, memory, motor control, language, spatial reasoning, not to mention imagination, also make art one of the most complex human activities [6].

According to Daly about creativity, any indicators include "4P's:" the person, the process, the product, and the "press" or environmental influence. In this view, creativity is not something that one either does or does not possess; instead, all individuals are capable of demonstrating creativity to some degree [7]. For the word "creativity," is refers to the activity with an end, not in itself but the achieving of a goal different from the mere self-satisfaction. The quality or ability to create are new ideas and inventive originality. It is the ability to develop creative thinking, like the ability to communicate or learn. It is a meta-competence applicable to different fields (arts, science, technology, business) [8]. Art teaching in grade 6 of elementary students is beginning from gave them more information about sculpture then they are talking about innovation to think about what will they do for the next practice. The teacher and the lecture have been trained every step. This practice is doing at an outing class. According to $4 \mathrm{P}$ concepts to do creativity exercising, so the teacher and the lecture are preparing rules and instructions when we were accompanied them, like (1) Person: the learning process is using students as participants; (2) Process: making the concepts, visual reference for the objects, preparing tools, finishing; (3) Product: the artworks; (4) Press: accumulated practicing time. For the $4 \mathrm{P}$ we can see how the students can think creatively to understanding the aesthetic and visual. In the process, we can know how the students understanding "aesthetic objects" and how they form creativity.

Creativity measures the creative person, product, process, and environment. First are one of the approaches to studying creativity in the art that focuses on the proses of creation. This involves the search for aspects of personality or behavior that might correlate to present creative achievement or future proficiency as an artist (or a visually creative person). A good body of research has shown that creative people tend to share develop characteristics, many of which have also been connected to individual skills in art. Such individuals tend to be independent, resourceful, and spontaneous with tolerance for risks, conflict, or ambiguity. They are also often confident in their abilities and have low levels of cognitive or behavioral inhibition. These features may be assessed through standardized personality scales or observation. Second, most studies have focused on evaluating general creative ability using tasks such as creating figures or images that are conceptually similar to art-making. Although comparatively less common than other verbal measures, the use of figural creation is valued for two reasons. (1) As noted above, art is a domain in which individuals, especially children, can act in a primarily creative fashion. Thus, art-making is considered a particularly ecologically valid means of inducing creative action. (2) With its emphasis on visual problem solving, art offers an alternative to verbal tests of creativity, which may also not always overlap. Third, the process has proposed three stages: perception processing, extraction, and abstraction (in which significant features are delineated) and final execution. Fourth, creativity in art, as the result of domain-relevant skills relating to expertise developed through education and life experience, as well as essential motivation, intelligence, or talent [6].

Visual Arts Education (VAE) activities are known to stimulate and integrate multiple domains of learning that include cognitive, affective, physical (sensorimotor skills), personal, interpersonal, and social fields. In addition to stimulation and engagement with a full scope of areas, certain types of cognitive processes are enhanced and stimulated while creating works of art: attention, focus, and concentration, divergent thinking, visual-spatial awareness, image formation, memory, imagination, inspiration, and intuition [9]. An essential dimension of the visual arts curriculum is that "content" (i.e., themes, subject matter, art activities) is not specified. Instead, art teachers have autonomy to design programs which are underpinned by four curriculum "strands": (1) understanding the visual arts in context (investigating the relationship between the production of artworks and their backgrounds and influences); (2) developing practical knowledge (applying knowledge of conventions from established practice, using appropriate processes and procedures); (3) developing ideas (generating, developing and refining ideas in response to a variety of motivations); (4) communicating and interpreting (comparing ways in which ideas and art-making are used to describe meaning) [10].

The implementation of art education at the primary education level must consider that art education as a vehicle to play, which is educative and builds creativity. If we use art education as a means of education, then the approach must be following the objectives of art creation, even though 
we do not place their art as an educational destination. The method is the activity of managing and managing the implementation of active learning that involves all forms of interaction between students, teachers, and learning resources. This pattern is a direct transfer of knowledge or processes related to education [11]. Collaboration between lecture and teacher has given more interaction with the students. The project-based learning model gives students the flexibility of ideas and honing of responsibility towards the tasks were assigned. Students can explore their techniques, experiences, feels, and sensory production. A variety of psychotherapy techniques include a wide range, and art therapy is one wide field of psychotherapy, which in effect is a treating and healing method of psychological distress through the medium of art. This treatment is one of the ways helpful to abused children to express their feelings and thoughts and then to control their stress gaining coping skills. Visual arts, among different types of art, including two-dimensional visual arts (designing, drawings, and photographs) and three-dimensional arts (sculpture), is the most effective method to help these children. Visual arts include painting techniques, clay sculpture, collage, and photographs, each influencing the observer differently. For example, the use of drawings as "selfcreated picture books" helps children to portray the kinds and stages of child abuse and disclosures about them [12]. Visual arts education is learning creativity and honing their feeling. The sculpture is one kind of 3D visual art which making in such material as stone, wood, clay, fiberglass, and soft objects. For elementary students, making 3D artworks should be made using soft ingredients, doesn't complicate processing, and obtained quickly. Soap is one of the materials which the author has chosen.

Such arts learning is to understand the visual from the objects. According to Garjāne, understanding art is the relationship between the spectator and the work of art that is determined not only by every person's knowledge, experience, and needs but also by the intention of the work of art, its content and form. Importantly, that understanding about art is determined not only functionally but also structurally, i.e., representation schemes, ideas, general truths, elements of the meaning where the direction of the creative thought is reconstructed based on the previously mentioned elements. The understanding of art has an artistic nature [13]. Visual arts students learn to generate a meaningful and to form aesthetic symbol for an evident topic by using such design elements and principles as color, line, form, shape, space, texture, balance, proportion, perspective, movement, pattern, emphasis, repetition, rhythm, variety, harmony, and unity [14]. Because elements are essential for making the artworks, the teacher and lecture are trying to give them more information about that. Students have been brought to discuss how to make a sculpture with soap by themselves. According to Moorman, art can be used to develop observational skills in students and can provide an innovative mechanism for students to produce higher levels of awareness and sensitivity to change. The technique has been used to improve observational skills in a variety of ways in education [15].

Physical elements in a work of art include all the visual elements contained in an object. The items in question include lines, expressions, space, texture, color, light-dark [16]. Visual arts learning for elementary schools, essential visual elements are using to make artworks in two or three dimensions. In this article, the authors apply these elements to analyze the three-dimensional work of Grade 6 elementary school students, namely sculpture. Sculpture can be said to form art. This can be explained as a process of excellent artwork to produce three-dimensional works (tri mantra) that have volume, space, beautiful, and artistic. Forming is a new art activity (pure). Specifically, forming activities relate to sculptures such as sculpting and relief. The techniques informing or sculpting include cutting, sculpting, casting/ pouring, constructing [17]. Because of the assistance, including sculpture art, so the main object in which researching is making a sculpture from soap. Students do not get the theory of marble, but they can recognize which the artworks beautiful and exciting. To know about it, students also got information and knowledge about aesthetic. Aesthetics is a concept often associated with beauty. Historically, it refers to the branch of philosophy concerned with the nature and appreciation of art, beauty, and good taste. In the $18^{\text {th }}$ century, aesthetics took on a meaning relating to sensory pleasure and delight. Over the centuries, the concept of aesthetics has continued to take on different meanings in different fields, such as art, design, and architecture [18]. Talking about aesthetic is part of philosophy; it has related to the taste of someone. Every people have their interest in something they say. One of the main goals of scientific aesthetics is to explain how people value objects, events, places, and other people. Such explanations often focus on certain sensory features, including symmetry, complexity, or prototypicality, and are intended to apply to a broad range of situations, people, and objects. They, therefore, rely on 
identifying regular response patterns and general perceptual, cognitive, and affective processes. According to Corradi e.t.al, the situations, people, and objects are an inseparable unity. Every student has got their moments in life, and recognizing objects become interpret differently. They can represent the purpose of what they had not known before or just looked at a moment [19].

During the artistic process, people can develop affection and emotion. Therefore, the aesthetic experience can be divided into two categories: aesthetic judgment and aesthetic feeling, and both are relatively independent. While the aesthetic sensibility is the actual emotion experienced by the experiencer, not the emotional that the stimulus displays, expresses or implies (distinguish of emotional perception and sensitive induction). The aesthetic feeling is traditionally confined to perceptual input. Therefore, the aesthetic sensibility is caused by visual and auditory sensations, which is generated by the cognitive processing response to these inputs [20]. Aesthetic feeling related to the person inside, which reveals yet or digging more. Aesthetics is about what is pleasing to the senses: does something look, feel, smell, sound, or taste good. Many artists and philosophers have attempted to 'rationalize' aesthetics. The $18^{\text {th }}$-century Kantian disinterested aesthetics and the anti-beauty stance of $20^{\text {th }}$-century modernism both are attempts to redefine sensual judgments in more intellectual, disembodied terms. But ultimately aesthetics is located in our bodies: beauty is a form of truth that is validated by physical experience [21]

\section{Method}

The research method is using descriptive research with a qualitative approach. Qualitative methods consist of observation, interviews, or document review. Taylor explained that adjusting this method is more comfortable when dealing with plural facts. Besides, this method presents the nature of the relationship between researchers and respondents directly. This method is more sensitive and adjusts to the many sharpening of the mutual influence on the patterns of values encountered [22]. The author has been put sampling from elementary students in Grade 6. There are 25 children. Data collection techniques carried out by interview, observation, and document review. The author interviewed students when they are studying the Seni Budaya dan Keterampilan (SBdP) lesson. Interviews are conducting in an unstructured, informal manner, there are no guidelines, starting with exploring a general topic together with participants [23]. For another data, the author using the observation that divided into observation and participatory observation. Observations are researchers observing participants as an outsider; researchers can be present in the daily lives of the participants but do not take any role in their activities. While participatory observation is an activity carried out by researchers who participate in the daily activities of the participants [24]. The type of observation has chosen for this study is the observation students' process of making soap statues. The first step, they are preparing material, tools, and media. They are using soap and carving with a knife or cutter.

The next collecting data are getting with interviews. There are one of the most widely used research data collection tools that enable researchers to collect data from respondents in a variety of situations and contexts [25]. The types of interviews in qualitative research consist of structured interviews, unstructured interviews, and semi-structured interviews [26]. In this case, the author is using the kind of unstructured interview, which is informal; there are no guidelines whatsoever, starting with exploring a general topic together with participants, the author using the unstructured interviews to dig information when they are making sculptures outside class. Dialogue situation with students has arranged more relaxed and sustainable so that they can be getting more data and information. The authors also added a collection technique with document review that documents are all material things in written form made by humans, all records both in paper (hardcopy) and electronic (softcopy) such as books, mass media articles, diaries, manifestos, laws, minutes, blogs, pages web, photos, and so on [27]. An important role in qualitative research because the discovery of knowledge or theory must be supported by detailed data and not supported by those from memory. So that in this study, the author using the reflective journal on learning since students following the class, getting visual references, making design, and caving on to the soap. Data analyzed using a narrative technique approach to reading or writing. Narrative analysis as a tool for organizing and presenting research data in a logical, structured, and systematic manner, while reading in the sequential analysis is interpreting the meaning of data in the form of narrative [28]. Data have analyzed by narrating sequence the process of making soap sculptures. 


\section{Results and Discussion}

"Pengiriman Dosen Ke Sekolah (PDS)" is one of the "Kemenristekdikti" programs that delegating lectures in the Faculty Teaching Training and Education of Universitas Ahmad Dahlan Yogyakarta teaching at school. The author got a great moment when teaching the elementary students and doing a collaboration with the class teacher. The course has chosen "Seni Budaya dan Prakarya (SBdP)," and it was suitable with Core Competencies and Basic Competencies for Grade 6 in elementary school. The number of meetings was carried out eight times by completing the two essential competencies, namely 4.1 and 4.4. Every meeting, the author and class teacher took turns or collaborated in delivering material and mentoring the learning process. We chose to use outside the classroom as a practical activity. We played a video on how to make a sculpture from soap through the projector screen. Every student was paid attention, and questions began to emerge. Their common problems are related to how to make the sculpture, the level of difficulty, and their abilities. Their average response well, and they were interested in building by themselves. Students can make sculptures from soft material, namely bath soap individually. The manufacturing process is carried out with assistance from lecture and teacher, starting from the provision of equipment, light discussion, work instructions, until finishing the artworks.

Each student practice with preparing tools which suggested and must bring for the next meeting. Even students brought additional tools and materials that they thought can do exercise easily. Some have tried at home and brought it into school and shown it to the lecture and class teachers. They imagined what objects will be doing and the average like animals (fish), flower, cartoon, leaf, and fruit. Product, the soap was carved, is cleaned with a soft brush so the shavings can be lost, and the artwork becomes cleaner. Process, For the tools, the lecture and class teacher asked students bringing some tools needed, such as a chopper and knife to carve the soap. Before slicing, students must make a design on paper with a pencil and then cutting the pattern with a pair of scissors and stick it on the surface of the soap. Then, they are starting to carve according to the design. If the contents of the cutter are not sharp enough, they must be replaced immediately so the artworks will be better, especially in the location of volume, indentation, and plasticity of the object. Then, the lecture and class teacher aim more at simple objects so that they can enjoy their practice. Besides that, students were directed to bring material which getting more comfortable and familiar.

According to the visual arts curriculum has four curricula "strands"; (1) Understanding the visual arts in context (investigating the relationship between the production of artworks and their backgrounds and influences): the lecture and class teacher are teaching sculpture contextual with soft material. Students were got information and can imagine the relief in smaller media; (2) Developing practical knowledge (applying knowledge of conventions from established practice, using appropriate processes and procedures): the lecture and class teacher are giving work instruction for making sculptures and inviting them to an outing class. They are exploring media, talking with their friends, discussion and ask each other, and relaxing; (3) Developing ideas (generating, developing, and refining ideas in response to a variety of motivations): the lecture and the class teacher let them imagine, exploring, and mingle with their friends; (4) Communicating and interpreting (comparing ways in which ideas and art-making are used to describe meaning): students were allowed to exchange ideas with friends, especially for those who have difficulty what sculpture will make. We are accompanying our students and giving an explanation about the visual arts in the class. The students are listening to us and writing down on their notes about the preparation. At the next meeting, students are bringing material and equipment which they must use. Figure 1 is one of the collaborations between lecturer and tutor teacher.
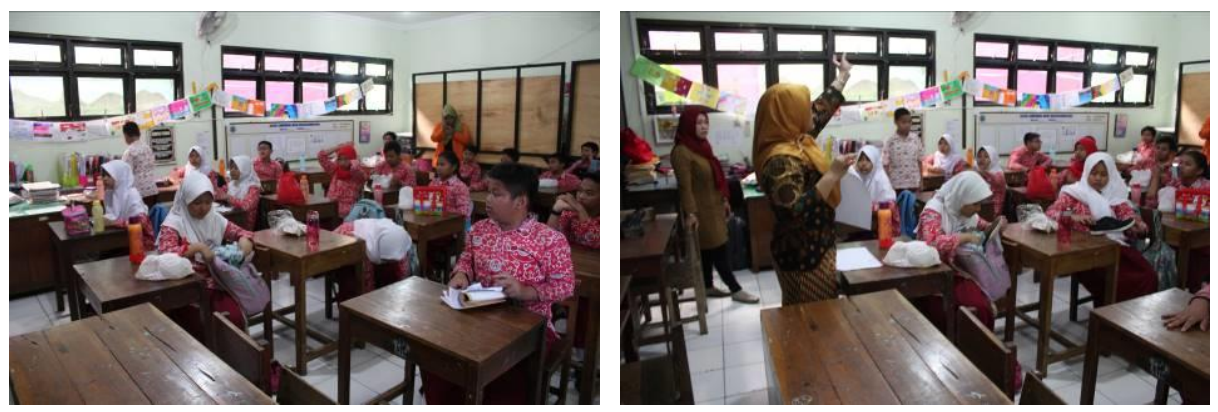

Fig. 1.Work Instruction and Preparing (Photographer: Vais Febrian, 2019) 
Next activity, we are doing the exercise to make sculptures. We are also interacting with the students about the process and talking to each other if their friends can't finish the artwork. They can help their friends to fix sculpturing material. Figure 2 lecturer and tutor teacher assistance in the outing class.
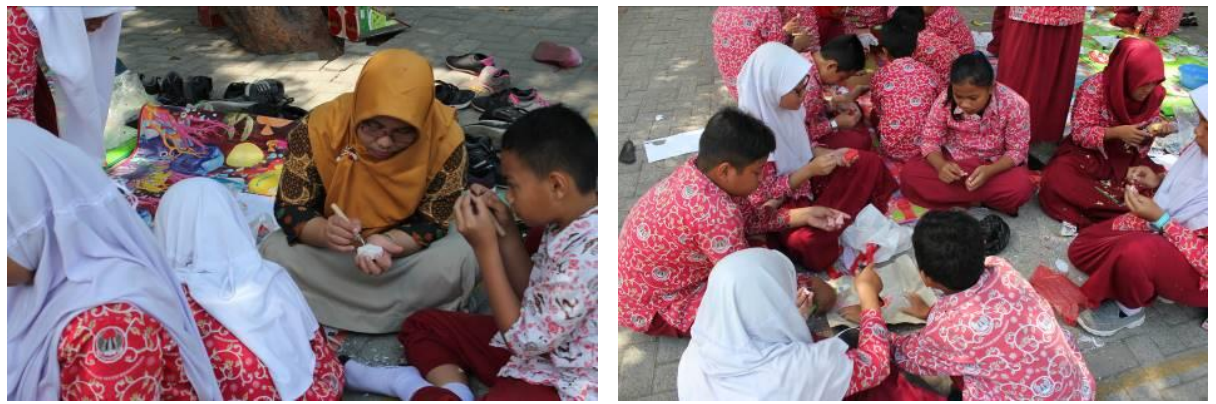

Fig. 2. Assistance in the Practice of Making Sculpture (Photographer: Vais Febrian, 2019)

Figure 3 is talking about the artwork after finishing with carving techniques on to the bath soap (left). And the right figure, it is one of the students who captured by the photographer which making advertising with poster color and brush. They learned wet media for exploring techniques and ideas.
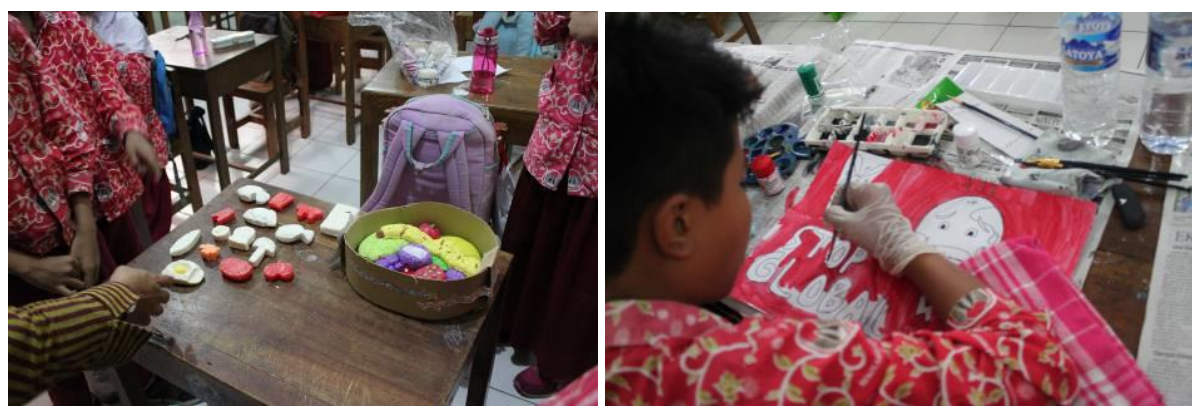

Fig. 3. The Sculpture and Process of Making Advertising (Photographer: Vais Febrian, 2019)

They are also trying to make gradation from three colors until seven color levels. Furthermore, learning activities can be described in more detail following aspects of a person, product, process, and the environment. Elementary students in 6th Grade are making sculptures, and advertising artworks have used more tools and materials. Every artwork has difficulty levels; the lecturer and tutor teacher are collaboration to solve. Figure 4 is about lecture and tutor teacher assistance for the students using poster color and mixing between primary color (red, blue, and yellow).

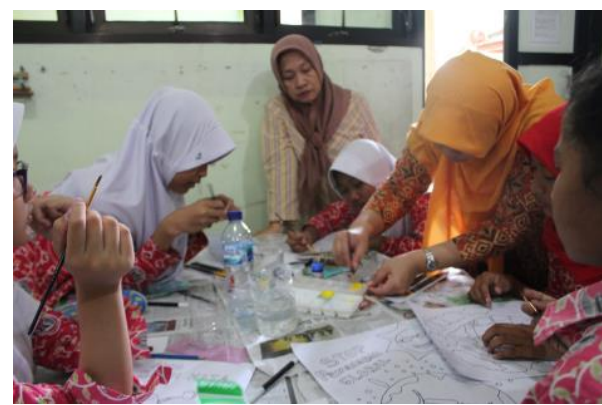

Fig. 4. Lecturer and Tutor Teacher Assistance (Photographer: Vais Febrian, 2019)

Meanwhile, to analyze the creativity of the 6th-grade elementary students' analysis, the author uses 4 aspects of assessment, such as a person, product, process, environment. The results of the analysis are explained in Table 2.

Table 2. Creativity Measure of $6^{\text {th }}$ Grade Elementary Students Analysis

\begin{tabular}{ccc}
\hline Aspect & Indicator & Creativity Measure Analysis \\
\hline Person & Creativity in art focuses on the creator. & Students were enthusiastic in participating in \\
& Aspects of personality or behavior. & each lesson has shown by their always complete \\
& Individual skills in the art such as independent, & presence in class. \\
\hline
\end{tabular}


resourceful, and spontaneous with tolerance for risks, conflict, or ambiguity.

Confident.

Product

Process

Environment

Education and life experience, as well as essential motivation, intelligence or talent.
Students showed an attitude of being able to obey the rules following the learning agreement at the beginning of the meeting.

Students can associate an art lesson with everyday life as an example when they arrange shoes on a shelf.

Students showed confidence when expressing opinions.

Students prepared tools and materials according to the lecturer and tutor teacher direction last week. They are following the instruction and writing on to their notes.

The lecturer and tutor teacher is explaining advertising by bringing some example artworks. Students have given assignments writing their exposure to the picture, which shows for the LCD.

Students replicate the objects around them into a sculpture design made from bath soap. Students play a practical tool following the curve of the object that has been designed.

The average of design has chosen fauna objects. In the advertising artworks, students have managed the object according to the theme chosen by adding a few explanatory sentences to make it easier for the audience to interpret the work created.

Object selection, both from sculpture and advertisement, has referred to objects in the environment around the students.

The materials used to make sculptures and advertising are also easily found around the students.

Some students are carrying outside specified tools such as chisels, which are usually used for high print graphic arts when making advertising artworks.

Students can memorize the steps of doing works, both sculpture, and advertising. Lecturer and tutor teachers are giving two-dimensional visual arts insight by showing visual references.

Students are making object design which

carving on HVS paper. There are cutting according to soap size, and then they draw the design such as fish, flowers, clam, and so on.

Students still have difficulty in combining

objects and colors because some of them feel less confident, so use the colors that are already in the poster paint bottle.

Some students have difficulty in interpreting the tasks of lecturers and tutors, especially in the work of billboards, where they have a relatively similar perspective in terms of determining the theme.

The most chosen themes are earth and global warming.

The students are creating the artworks, both sculpture and advertising that were good to the final stage are finishing.

Students are making the sculpture from soft material at an outing class and have assistance from the lecturer and tutor teacher.

The students can express opinions between the material presented and the conditions in their surroundings.

Students can study the assignments given with objects in the surrounding environment. 
According to Table 2, the visual aesthetic of $6^{\text {th }}$-grade elementary students tends to familiar objects which their environmental surroundings. However, additional recognition of visual references needs to be given so that the object images do not tend to have something in common. For them, beautiful objects are the objects that are often seen, everywhere, and have a relatively low level of difficulty.

\section{Conclusion}

Visual aesthetic understanding for elementary students comes from how we can invite them doing practicing at outclass and let them look for reference from many sources. Creativity reveals from combining person, product, process, and environment. The involvement of the lecturer and tutor teacher in the learning process is constructive for students in representing ideas and ideas. Besides, the process of mentoring during practice can control the attitudes of those who tend to play around still.

\section{Acknowledgment}

The author is giving thank you for the "Pengiriman Dosen Ke Sekolah" committee about this program, which provides an opportunity for me to be able to develop my potential and learning. Furthermore, they also thank the Faculty of Teacher and Education Science of Universitas Ahmad Dahlan Yogyakarta, Indonesia, for their support and trust in be carrying out this noble task. The author does not forget the author also expressed thanks to the Elementary School Teacher Education Department as an author working Homebase.

\section{References}

[1] R. I. Kementrian Kesehatan, "Kata Kerja Operasional (KKO) Edisi Revisi Teori Bloom," BPPSDMK, 2018. [Online]. Available: bppsdmk.kemkes.go.id > pusdiksdmk > wp-content > uploads > 2018/03.

[2] D. Sparks, J. Zhang, S. Bahr, and J. Ralph, "Public Elementary and Secondary School Arts Education Instructors," Natl. Cent. Educ. Stat. NCES, vol. 85, pp. 1-28, 2015.

[3] M. Cahnmann-Taylor and R. Siegesmund, Arts-Based Research in Education: Foundations for Practice, Second Edi. New York: Routledge, 2018.

[4] M. S. Lindauer, "Interdisciplinarity, the Psychology of Art, and Creativity: An Introduction," Creat. Res. J., vol. 11, no. 1, pp. 1-10, Jan. 1998.

[5] R. Vishkaie, "The Role of Wearable Technology in Children's Creativity," in Proceedings - 2018 International Conference on Cyberworlds, CW 2018, 2018, pp. 443-446.

[6] M. Pelowski, H. Leder, and P. P. L. Tinio, "Creativity in the visual arts," in The Cambridge Handbook of Creativity across Domains, 2017, pp. 80-109.

[7] S. R. Daly, E. A. Mosyjowski, S. L. Oprea, A. Huang-Saad, and C. M. Seifert, "College students' views of creative process instruction across disciplines," Think. Ski. Creat., vol. 22, pp. 1-13, 2016.

[8] F. Saliceti, "Educate for Creativity: New Educational Strategies," Procedia - Soc. Behav. Sci., vol. 197, pp. 1174-1178, 2015.

[9] A. G. Richards et al., "Visual Arts Education improves self-esteem for persons with dementia and reduces caregiver burden: A randomized controlled trial," Dementia, 2018.

[10] J. Smith, "Curriculum, Assessment and Pedagogy: How These Dimensions are Enriching Visual Arts Education for Ethnically Diverse Students in New Zealand Secondary Schools," J. Educ. Cult. Stud., vol. 3, no. 3, p. p311, 2019.

[11]T. M. Johan, A. Ambiyar, and J. Jamal, "Development of Competence-Based Art Learning Model in Primary School Students," 2019.

[12] M. Samadzadeh, M. Abbasi, and B. Shahbazzadegan, "The Effect of Visual Arts on Education of Coping Strategies in Annoyed Children,” Procedia - Soc. Behav. Sci., vol. 83, pp. 771-775, 2013.

[13]B. Garjāne and A. Kairiša, "Promoting the Understanding of Art in Art School Students," Educ. Reform Compr. Sch. Educ. Content Res. Implement. Probl., p. 5, 2015. 
[14]K. Ulger, "The effect of problem-based learning on the creative thinking and critical thinking disposition of students in visual arts education,” Interdiscip. J. Probl. Learn., vol. 12, no. 1, 2018.

[15]M. Moorman, "The Meaning of Visual Thinking Strategies for Nursing Students," Humanities, vol. 4, no. 4, pp. 748-759, 2015.

[16]N. Kim, "A History of Design Theory in Art Eeducation,” J. Aesthetic Educ., vol. 40, no. 2, pp. 12-28, 2006.

[17] R. M. Simon, “Sculpting the Family,” Fam. Process, vol. 11, no. 1, pp. 49-57, 1972.

[18]K. Oyibo, B. Olabenjo, I. Adaji, R. Orji, and J. Vassileva, "The interplay between classical aesthetics, expressive aesthetics and persuasiveness in behavior modeling," in Proceedings of the 32nd International BCS Human Computer Interaction Conference, HCI 2018, 2018.

[19] G. Corradi, E. G. Chuquichambi, J. R. Barrada, A. Clemente, and M. Nadal, "A new conception of visual aesthetic sensitivity," Br. J. Psychol., 2019.

[20] Y. Gao and L. Xie, “Aesthetics - Emotion Mapping Analysis of Music and Painting," in 2018 1st Asian Conference on Affective Computing and Intelligent Interaction, ACII Asia 2018, 2018.

[21] G. Kuipers, T. Franssen, and S. Holla, "Clouded judgments? Aesthetics, morality and everyday life in early 21 st century culture,” Eur. J. Cult. Stud., vol. 22, no. 4, pp. 383-398, 2019.

[22] S. J. Taylor, R. Bogdan, and M. DeVault, Introduction to Qualitative Research Methods: A Guidebook and Resource. John Wiley \& Sons, 2015.

[23] R. G. Burgess, “The Unstructured Interview as a Conversation,” in Field research, Routledge, 2003, pp. $177-182$.

[24]B. Rogoff, “Observing Sociocultural Activity on Three Planes: Participatory Appropriation, Guided Participation, and Apprenticeship,” Pedagog. Pract. Cult. identities, pp. 58-74, 2008.

[25] J. P. T. Higgins and J. J. Deeks, "Selecting Studies and Collecting Data," Cochrane Handb. Syst. Rev. Interv. Cochrane B. Ser., pp. 151-185, 2008.

[26] N. King, C. Horrocks, and J. Brooks, Interviews in Qualitative Research. SAGE Publications Limited, 2018.

[27]P. J. Bretschneider, S. Cirilli, T. Jones, S. Lynch, and N. A. Wilson, Document Review as a Qualitative Research Data Collection Method for Teacher Research. SAGE Publications Ltd, 2017.

[28] M. Cortazzi, Narrative Analysis. Routledge, 2014. 